\title{
Comics and Translation with a Multimodal Perspective in the Early Republican Era
}

\author{
Göksel Öztürk ${ }^{1}$ and Aslı Özlem Tarakçığlu
}

\begin{abstract}
Comics has a "hybrid" interaction emerging from the "interplay" between pictorial and textual elements. However; many studies on translation of comics focus on texts but disregarding pictures. Analyses performed by focusing on textual elements disregard pictorial and textual interactions, which is a kind of regression of the multimodal aspect of comics. One of the aims of this article is to treat comics on its own autonomy since comics is generally considered as a tool of other research areas. The present study investigates the functions of pictures and texts in the context of "pictorial turn" by keeping multimodal approach in perspective. Translated comics to be analysed are the first translated comic strips into Turkish after the alphabet reform. The very first concealed translations of comics during the Early Republican Era are analysed with a multimodal perspective considering historical context as well as cross-media interactions of pictures and texts. As the first Turkish translations of comics were published in children's periodicals in the early Republican era, this article practices on multiple layers such as transformation of media, culture planning, and manipulation.
\end{abstract}

Keywords: comics; translation of comics; multimodality; Flash Gordon.

\section{Introduction}

Many studies regarding translation of comics take their roots on text analysis, which is against the nature of comics whose power of expression arises from the interaction or "interplay" between pictorial and verbal elements. Reposing on the interaction between these elements, comics conveys a multimodal message, a "blend" of different semiotic resources.

What "cultural turn" means for translation studies is necessarily equivalent to what "pictorial turn" means for translation of comics. As textual materials are loaded with cultural items, so are pictorial elements. So long as translated textual materials are practised upon exploring reflections of a period, pictorial translated materials can be referred likewise.

In the present article, the first translated comics in Turkish history following the alphabetic reform are discussed within a multimodal perspective. The research questions are; does the relation of text and image change in the process of translation, what strategies are used in translating comics?

\footnotetext{
${ }^{1}$ Göksel Öztürk, Lecturer, Bursa Technical University, Bursa. Turkey. E-mail: gokseledu@gmail.com.

2 Aslı Özlem Tarakçıŏlu, Associate Professor, Ankara Hacı Bayram Veli University, Ankara, Turkey. E-mail: asli.tarakcioglu@hbv.edu.tr.

Acknowledgement: This article has been extracted from the PhD dissertation of Göksel Öztürk and supervised by Aslı Özlem Tarakçioğlu.
} 
Besides, seeking answers to these questions, comics elements such as panels, captions, colour, perspective, speech balloons and page layout are analysed in the process of translation. Textuallinguistic norms in translating comics are discussed to maintain embodiment with the help of Flash Gordon's translation regarding domestication and foreignisation.

\section{Defining Comics}

Scott McCloud (1994) defines comics as "juxtaposed pictorial and other images in deliberate sequence, intended to convey information and/or to produce an aesthetic response in the viewer" (p. 9). R. C. Harvey (2009) opposes this definition, stating that it excludes comic strips. According to Will Eisner comics is "the arrangement of pictures or images and words to narrate a story or dramatise an idea" (1985 p. 5). Pascal Lefevre and Charles Dierick define comics as "the juxtaposition of fixed (mostly drawn) pictures on a support as a communicative act (1998, p. 12). Thierry Groensteen attaches importance to its narration quality and defines comics as "a visual narrative, a story conveyed by sequences of graphic, fixed images, together on a single support" (2013, p. 108). As can be deduced from these definitions, picture or image has an indispensable place in comics, and what is more; the image is the steady pair of compasses. What makes comics unique is the tidal traffic between the picture and text.

\section{A Brief History of Comics}

Although "sequential" pictures can be found on the walls of caves thousands of years ago, Randy Duncan and Matthew Smith (2009) find it impossible to set the origins of comics on the walls of caves as they lack "production, delivery and function" and take the efforts to find roots on Greek vases or Bayeux tapestry are political (pp. 20-21). Levent Cantek (2014) is of the opinion that comics are to be published and continue for some time. Despite the dissidence about the origin, William Hogarth (1697-1764) is thought to be the key artist in the history of comics with his zigzag form in his engravings. Following Hogarth, Rodolphine Töpffer is considered to be one of the most influential artists in comics. Thierry Smolderen (2014) indicates that Töpffer's Histoire de

Picture 1: Billy the Bully and Ranting Dan

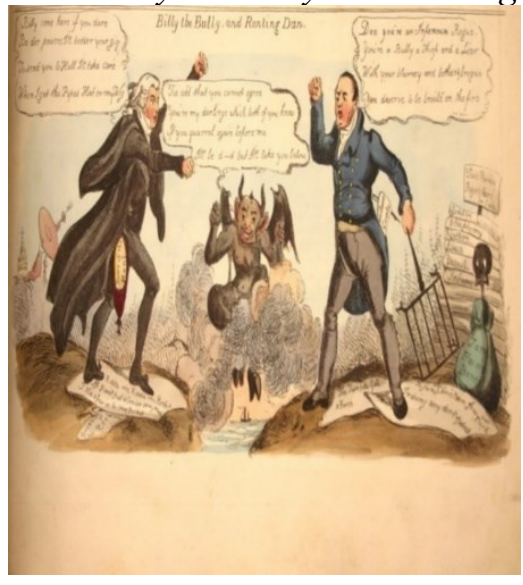

Source: Grove (2016), p. 2. (Digitally Coloured)
Monsieur Cryptogame was published in a French magazine in 1845 and its impact was felt after 40 years.

It is the comic strip that led comics to be known worldwide. According to Laurence Grove (2016), the first published comic strip is Billy the Bully and Ranting Dan which was published in Looking Glasgow Class, a Scottish caricature magazine, in 1825 .

Towards the end of $1880 \mathrm{~s}$ the harsh competition in newspapers gave comics an opportunity to be known worldwide. Comic strips started to have extensive media coverage in Sunday supplements. The milestone in the modern comics is Yellow Kid by Richard F. Outcault, which is followed by Katzenjammer 
Kids (Rudolph Dirks), Happy Hooligan (Frederick Opper) and Mutt and Jeff by Bud Fisher (Harvey, 2009).

Picture 2: Yellow Kid (1896)

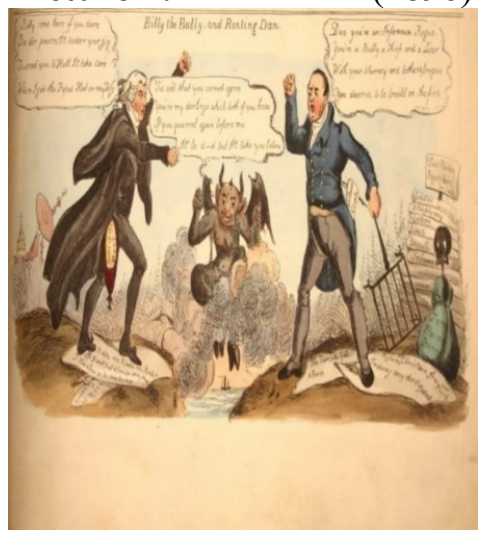

Source: Ohio State University Digital Library
Picture 3: Happy Hooligan

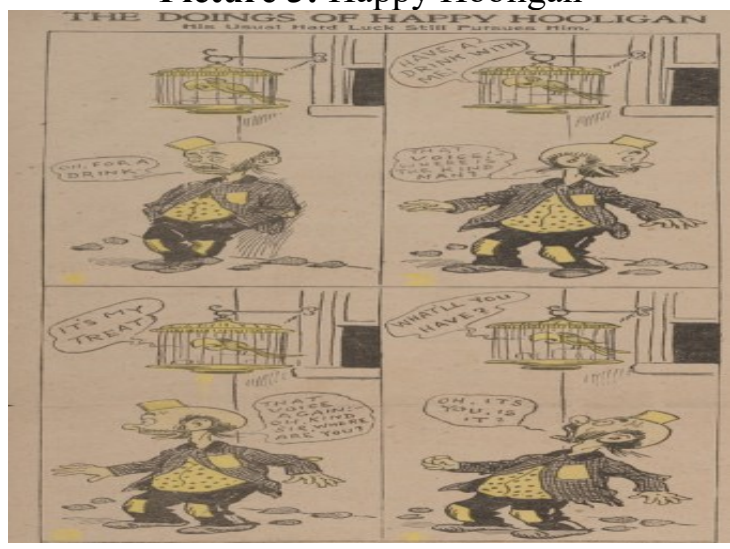

Source: Ohio State University Digital Library

Pictures 4 and 5: Cover pages of Funnies and Funnies on Parade
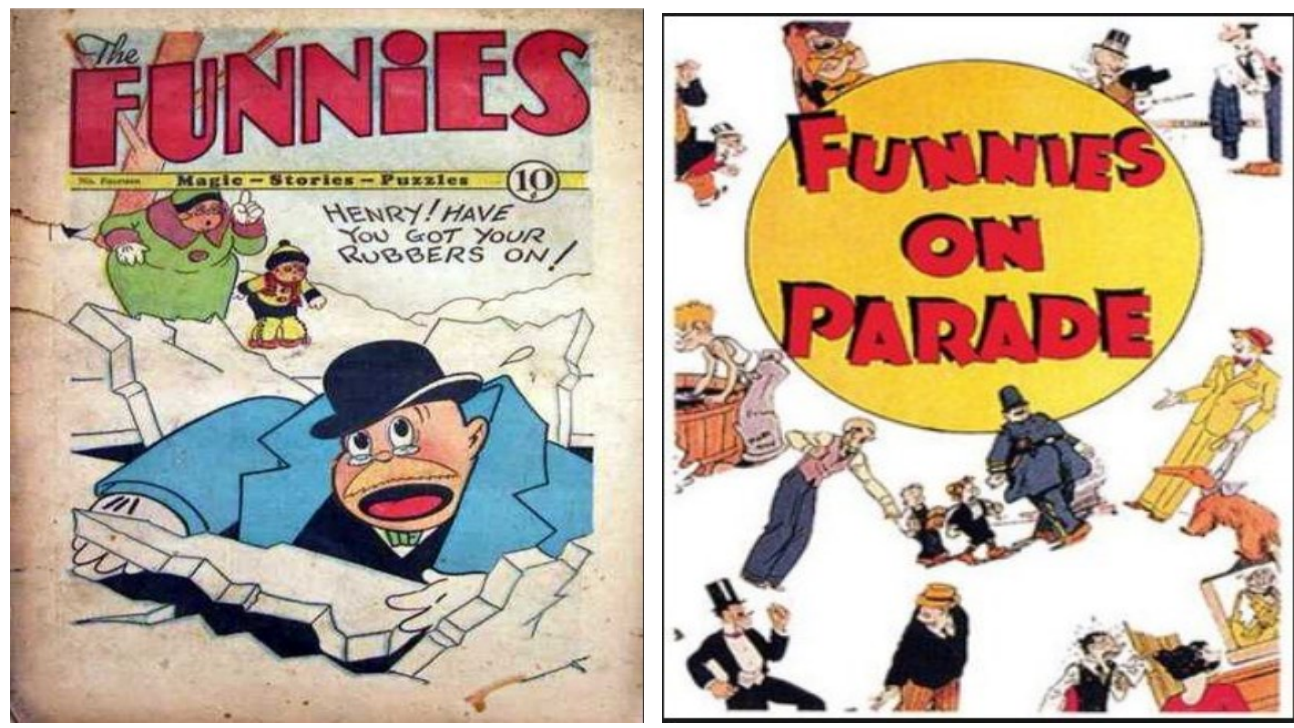

The harsh competition among newspapers gained momentum with the involvement of syndicates into it, which were producers of comics. Syndicates were selling comic strips to newspapers which cannot afford to produce them. Unlike newspapers producing comics, syndicates started selling publication rights to other newspapers and magazines in different countries. This led to a surge in the number of comics fans all around the world. However, with the involvement of publishing companies into the market, comic strips were evolved into comic books. To illustrate, Dell Publishing Company debuted 16-page The Funnies magazine in 1929, which was followed by 8-page Funnies on Parade published by Eastern Color Printings (Duncan \& Smith, 2013). 
The first development of comics owes its popularity to imitations from titles to characters. The competitive environment led the producers not only imitate others but also create new unconventional comics. These were such comics that while some of them are rare comics that are even known today, others led the flare of comics opposition resulted in the prohibition of publication in many countries and even burning of comic books in the USA towards the 1950s.

Picture 6: Burning of comic books. Time

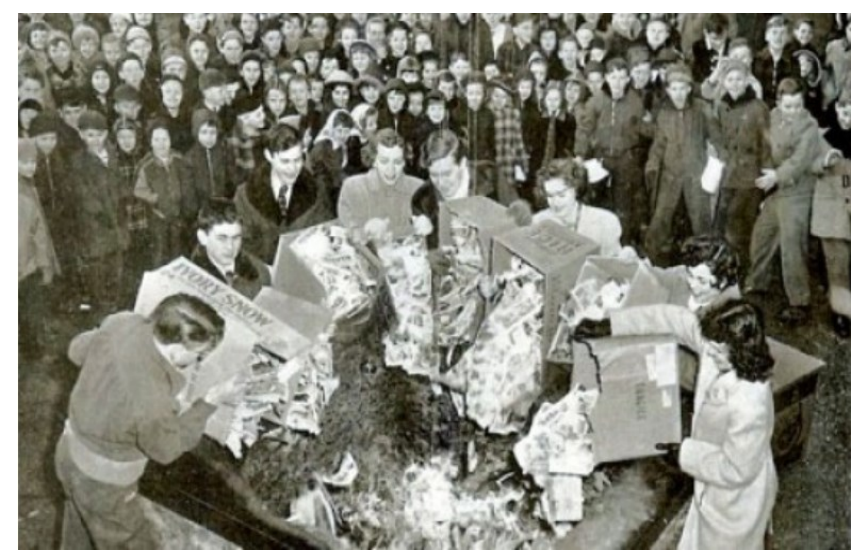

Source: cbldf.org/2012/06/1948-the-year-comics-met-their-match/

\section{Multimodality}

Comics as a "hybrid" form of picture and text has a more complicated structure than it is common definition as consecutive pictures (Rota, 2008). Groensteen (2007) takes this picture and text relation as an intersection. To clarify it better to identify the functions of picture and text in comics. Is the text a text in comics? Upon conveying its message to the receiver, a text becomes a picture a part of the whole panel, so the picture is the steady pair of compasses. As different modals text and picture fuse a multimodal message. Roland Barthes (1982)

offers two functions of a verbal message; anchoring and relaying. In anchoring "firstly, the text constitutes a parasitic message designed to connote the image ... in other words ... the image no longer illustrates the words; it is now the words which, structurally, are parasitic on the image" (Martinec \& Salway, 2005, p. 344). As for relay "here text and image stand in a complementary relationship; the words, in the same way as the images, are fragments of a more general syntagm and the unity of the message is realised at a higher level" (Martinec \& Salway, 2005, p. 344). Barthes takes the relation either supportive or complementary. Kress and Leeuwen (2006) are of the opinion that communication is sustained with the combination of more than one modes. They elaborate these modes with a set of hypotheses:

“(a) human societies use a variety of modes of representation; (b) each mode has, inherently, different representational potentials, different potentials for meaningmaking; (c) each mode has specific social valuation in particular social contexts; (d) different potentials for meaning making may imply different potentials for the formation of subjectivities; (e) individuals use a range of representational modes, and therefore have available a range of means of meaning-making, each affecting the formation of their subjectivity; (f) the different modes of representation are not held discretely, separately, as strongly bounded autonomous domains in the brain, or as autonomous communicational resources in culture, nor are they deployed discretely, either in representation or in communication; (g) affective aspects of human beings and practices are not discrete from other cognitive activity, and therefore never separate or absent from representational and communicative behaviour; (h) each mode of representation has a continuously evolving history, in which its semantic reach can contract or expand 
or move into different areas of social use as a result of the uses to which it is put" (p. 41).

Martinec and Salway (2005) offer a system of image-text status relation developing from Barthes' text image relations.

Figure 1: System of image-text status relations

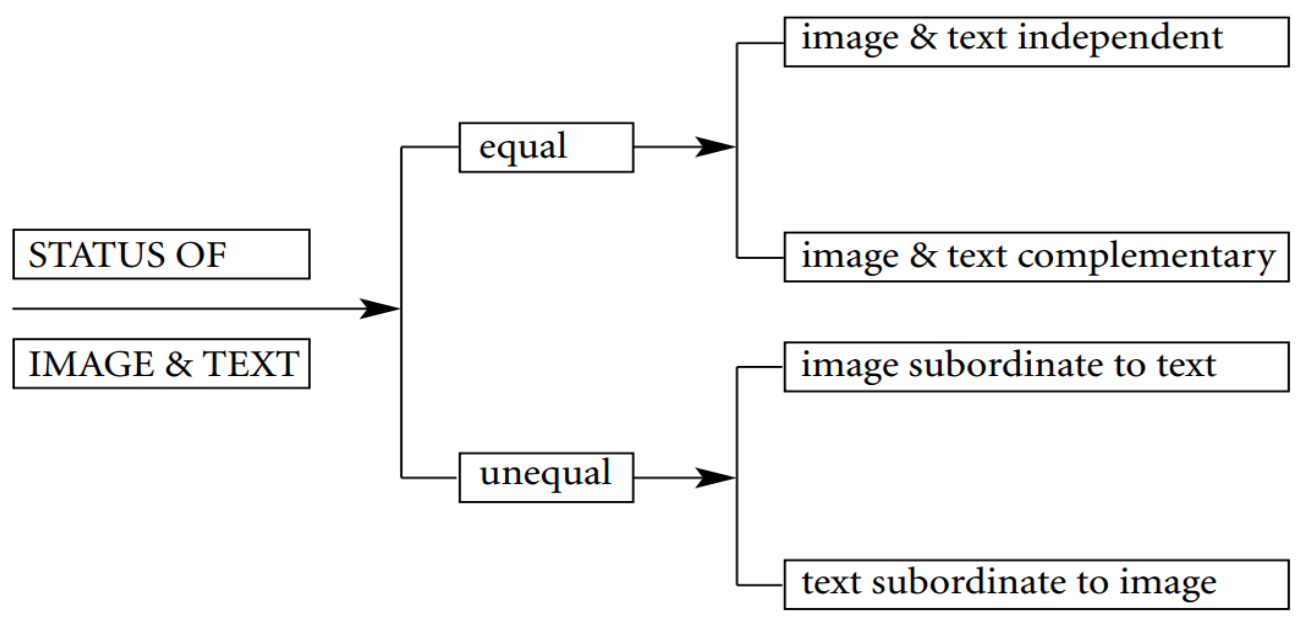

Source: Martinec \& Salway (2005), p. 351.

Neil Cohn (2013), drawing on his prior studies, offers four ways in terms of connection of images and texts:

1. Inherent: Relations where text and image are part of each other's structures (Example: writing appearing in the fictive world of the drawing).

2. Emergent: Relations where text and image are directly interfaced with each other. (Example: Word balloons and thought bubbles).

3. Adjoined: Relations where text and image are integrated but not interfaced directly. (Example: Text associated with image through captions or proximity alone)

4. Independent: Relations where text and image are fully separate. (Example: Academic writing using "See Figure 1") (p.36).

All these studies take textual and pictorial elements as different modes and suggest ways to define or clarify their function regarding their relations to each other, conveying a multimodal message to the receiver.

\section{Translating Comics with Multimodal Perspective}

Comics has its unique narrative sustained by the combination of pictorial and textual elements. Textual elements in comics are found in captions, speech balloons, thought bubbles, titles, indicia 
and part of the series. They placed in accordance with the colour, perspective and the moment of the story. Many studies focusing on translations of comics focus on the translation of texts, whereas text reflects only one mode of comics. In this respect, Katharina Reiss, who adopts a functional approach in translation, is the first translation scholar mentioning multimodal text types in her text typology: informative, expressive, operative and audio medial. Whereas there is no mention in her first typology, she mentions multimodal texts in audio medial text type (Dicerto, 2018). Klaus Kaindl (2004) takes a multimodal perspective as a systematic analysis and proposes a taxonomy to be used in humour translation of comics.

\section{Figure 2.}

\begin{tabular}{llll}
\hline Source Text & Target Text & Source vs Target Text & Source vs Target Text \\
Semiotic Type & Semiotic Type & Humour Technique & Language-picture relation \\
\hline \hline
\end{tabular}

\begin{tabular}{|c|c|c|c|c|c|}
\hline $\begin{array}{l}\text { A- Monomodal } \\
\text { Humour }\end{array}$ & $\begin{array}{l}\text { Monomodal } \\
\text { Humour }\end{array}$ & similar & changed & similar & changed \\
\hline $\begin{array}{l}\text { B- Monomodal } \\
\text { Humour }\end{array}$ & $\begin{array}{l}\text { Multimodal } \\
\text { Humour }\end{array}$ & similar & changed & changed & \\
\hline $\begin{array}{l}\text { C- Monomodal } \\
\text { Humour }\end{array}$ & No humour & --- & --- & --- & --- \\
\hline D- No humour & $\begin{array}{l}\text { Monomodal } \\
\text { Humour }\end{array}$ & changed & & changed & \\
\hline $\begin{array}{l}\text { E- Multimodal } \\
\text { Humour }\end{array}$ & $\begin{array}{l}\text { Multimodal } \\
\text { Humour }\end{array}$ & similar & changed & similar & changed \\
\hline $\begin{array}{l}\text { F- Multimodal } \\
\text { Humour }\end{array}$ & $\begin{array}{l}\text { Monomodal } \\
\text { Humour }\end{array}$ & similar & changed & changed & \\
\hline $\begin{array}{l}\text { G- Multimodal } \\
\text { Humour }\end{array}$ & $\begin{array}{l}\text { No } \\
\text { Humour }\end{array}$ & --- & --- & --- & --- \\
\hline H- No Humour & $\begin{array}{l}\text { Multimodal } \\
\text { Humour }\end{array}$ & changed & & changed & \\
\hline
\end{tabular}

Source: Kaindl (2004), p. 175.

Katerina Pastra (2008) proposes a detailed framework to be used in translation of comics with a multimodal perspective: a cross-media relations framework for modelling multimedia dialectics (COSMOROE). Pastra developed her framework using 500 caricatures with 2D, which takes 3 bases in relations: equivalence, complementary and independence.

Maria Grun and Cay Dollerup (2003) defines translation of comics as "constrained translation" in which there are losses and gains. As for translators who discovers the closure provided by pictorials may see the images in an untouchable position, which makes translation restricted i.e. "constrained". They may regret to interfere with the pattern. Michal Borodo (2015) states that comics translators prefer word to word strategy, condense text and ignore pictorial. Textual and pictorial elements can convey a message formed by the combination of them, which is one of the 
difficulties of comics translators. As pictorials can contain cultural items as texts do, it makes it more difficult as the cultural item is in an untouchable position for translators. This may lead translators to compensate it, mostly by strategies that are applied to the verbal, which undoubtedly intervenes the "interplay" between pictorial and text.

\section{Figure 3}

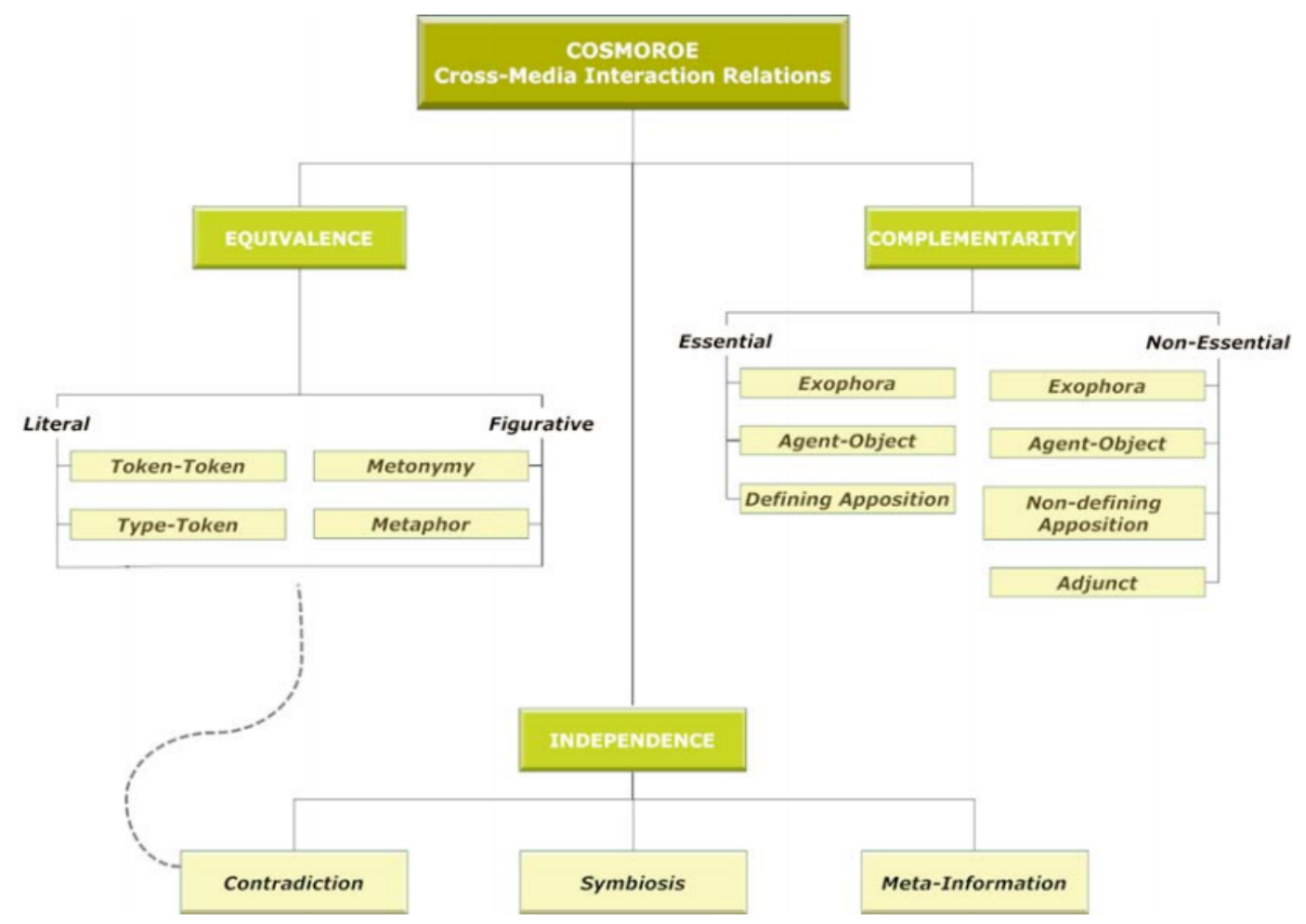

Source: Pastra (2008), p. 308.

Although most comic strips published in the 1930s did not intend children as their readers, it was not the case in Europe. Children periodicals welcomed these comic strips giving more coverage in their media. The change of the medium is one of the difficulties for translators as your target readers change as well as page layout and serial format. This may result in some adaptations in translation caused by readership and formatting. Emer O'Sullivan stated that the translator is more visible in children's books due to "asymmetrical communication" (Sinibaldi, 2016). Other than these, it may be confronted by ideological expectations in the target culture. The ideologies, whether intuitional or individual, may be effective in translation strategies.

\section{Early Republican Era and Translation}

With the Declaration of the Turkish Republic on October 29, 1923, many reforms and revolutions were introduced. The alphabet reform was introduced on November 1, 1928. The present article discusses the first Turkish translations of comic strips right after the alphabet reform. 
According to Itamar Even-Zohar's poly-system when the literary system is young as its repertoire may be limited. In this sense, it can be said that Westernization was adopted in order to develop the repertoire. As for translated texts Even-Zohar claims that in 3 conditions translated texts are placed in the centre of the literary system, which suits the young republic.

(a) When a polysystem has not yet been crystallised, that is to say, when a literature is 'young' in the process of being established; (b) When a literature is either 'peripheral' (within a large group of correlated literature) or ' weak, ' or both; and (c) When there are turning points, crises, or literary vacuum in a literature (Even-Zohar, 1978, pp. 193-194).

As a part of the Westernisation reforms, a government-supported translation committee was formed in 1939, which was followed by the establishment of the translation bureau in 1940 (Gürçağlar, 2008). All these developments indicate the government's role in cultural planning.

\section{Translation of Flash Gordon with a multimodal perspective}

As for the translation of the comics after the alphabet reform, the very first translations appeared in Çocuk Sesi (Voice of Children), a weekly periodical targetting children launched on December 27, 1928. It published some comic strips and caricature translations as well as translated short stories. All of its 464 issues were scanned and Flash Gordon, a widely known science-fiction comic strip, was chosen for the analysis since it had been published for a long period. As Flash Gordon translation doesn't follow the source patterns, 1615 target panels have been scanned and then matched with the 1615 source panels.

Flash Gordon debuted on January 7, 1934 in the USA in a Sunday supplement by Alex Raymond. Its production and distribution processes were carried out by King Features Syndicate. It was a milestone in comics history with its coloured vivid drawings. Besides, some of the technological devices that were introduced in the series became a reality after 80 years from its publication date such as visaphone. Flash Gordon's translation first appeared in Çocuk Sesi periodical on May 13, 1935 in the issue no 281 as a concealed translation. Domestication strategy was used in the translation of the name of the hero and it was translated as Baytekin, a Turkish name. Moreover, the heroine Dale Arden was translated as Bayan (Miss) Yıldız, a Turkish name.

It has been observed that additional texts have been added below the target panels which rephrase the speech balloon, caption or the picture. With a multimodal perspective, the additional texts have negative effects on the balance of the picture and text relation. The additional texts were added along with all 1615 panels. The reason for text additions in target panels may be the commitment to narration tradition, which makes it less risky for a new form introduced. Besides, as the source panels were not drawn for children, there might be a kind of adaptation for children.

Additional texts were also used for interpretation the image as well as containing dialogues given in speech balloon in the source panels. Although speech balloons contain texts, its a pictorial element positioned accordingly. Out of 1615 panels, speech balloons were deleted in 119 panels, which makes characters voiceless. Deleting the text imposes pictorials to be more powerful. In order to compensate this, additional texts contained dialogues. 
Picture 7 Issue No 353

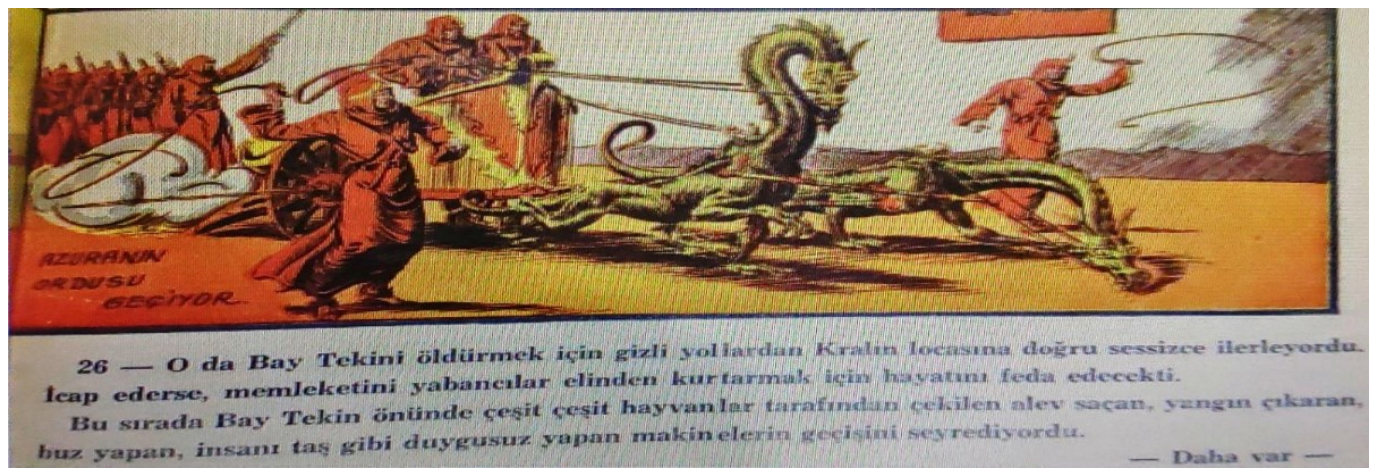

\section{Pictures 8 and 9: Flash Gordon - Baytekin}
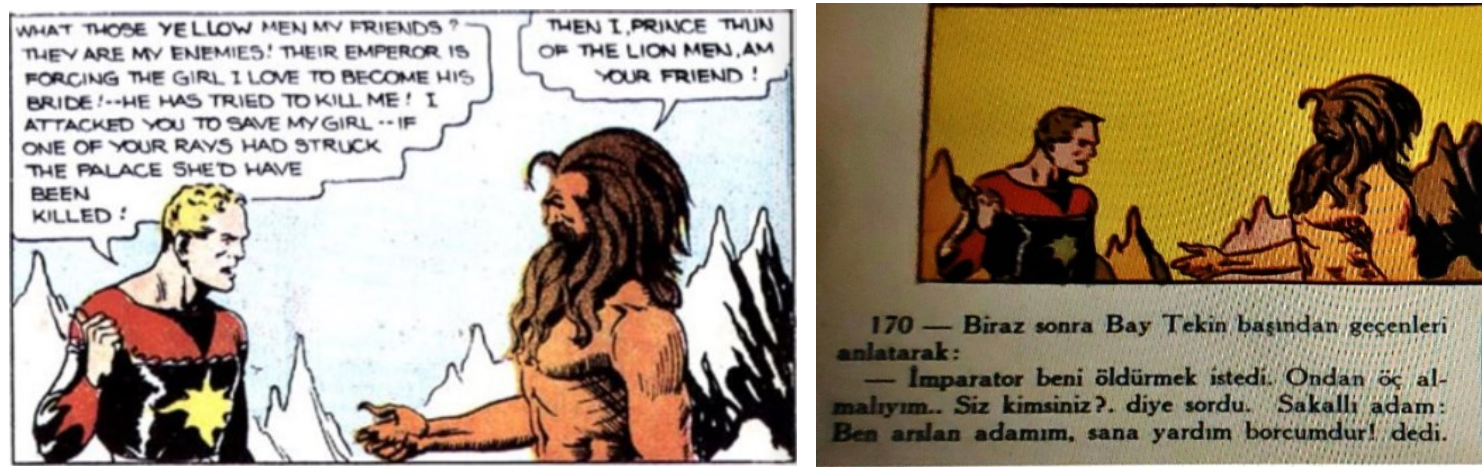

170 - Biraz sonra Bay Tekin basından gecenleri anlatarak:

- Imparator beni öldürmek istedi. Ondan öc almalyym. Siz kimsiniz?. diye sordu. Sakalli adam: Ben arslan adamım, sana yardım borcumdurl dedi.

\section{Picture 10 and 11 (Flash Gordon - Baytekin)}
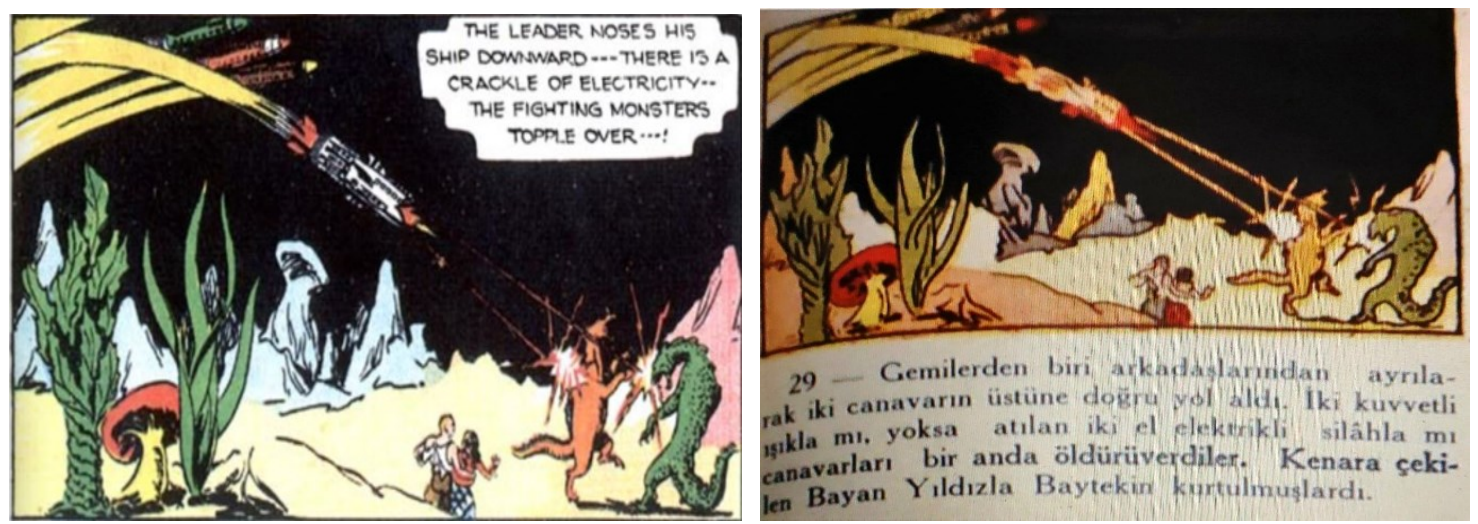

Captions provided information that is not shown on a panel. Information provided may be related to time, place, history or events. It has been observed that 363 captions were deleted in 1615 panels. Additional texts were used to compensate for the information conveyed by captions.

Colour is a key element in comics. As regards the use of colours, it can be concluded that colours were preserved insofar as publication capabilities. However, in some panels, it has been 
observed that colour was depicted, which is undermining the power or expressive quality of the pictorial.

Picture 12 Issue 283 “..... their faces were bright yellow"

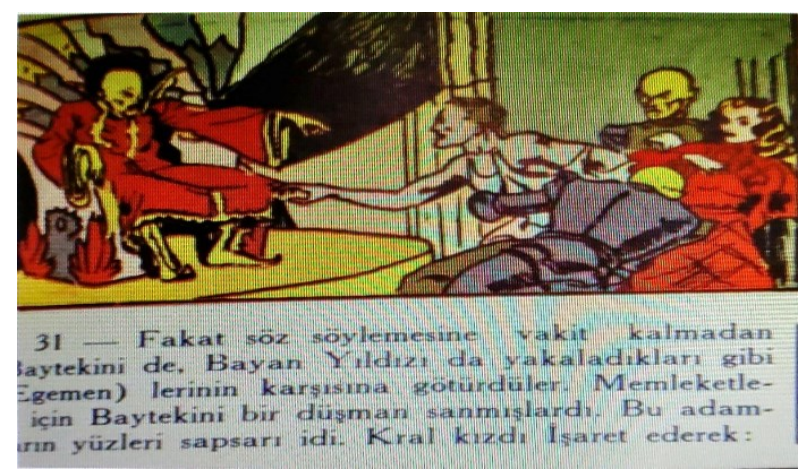

Perspective is the window angle in comics. It has been observed that there was no change in terms of perspective until 1942 when some panel and colour alterations were introduced. The panel sizes were mostly preserved. However, the tier of panels were changed in accordance with the adaptation to the target media. Gutter is the blank between the panels. It is the boundary between panels. Although the gutter was colourless in the source tiers, it was coloured in a few issues in target tiers.

\section{Picture 13 Issue 346}

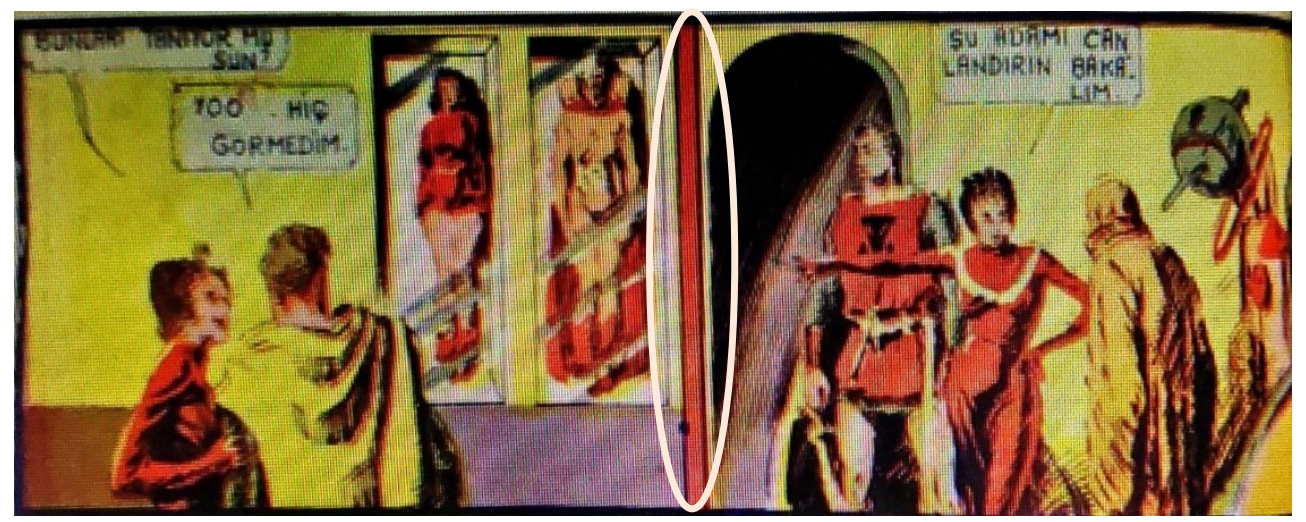

André Lefevere (1992) argues that translation is a rewriting and translated texts are affected by the poetics or ideology of the target culture. There are some examples of censorship in the translation of Flash Gordon. The censorship applied to both the target images and texts. As these practices were not consistent thought the series, it is hard to conclude whether they are institutional or individual choices.

82 cases of censorship were found in 1615 panels. One of them was the deletion of a panel. Out 81 panels, 1 panel depicting alcohol and 2 panels depicting kissing were censored. The remaining 78 panels were about modifying the clothes worn by women. The clothes were modified to hide naked parts of bodies. In terms of text, some words such as love, darling, outlaw and smuggler were deleted. 
Pictures 15, 16, 17 and 18
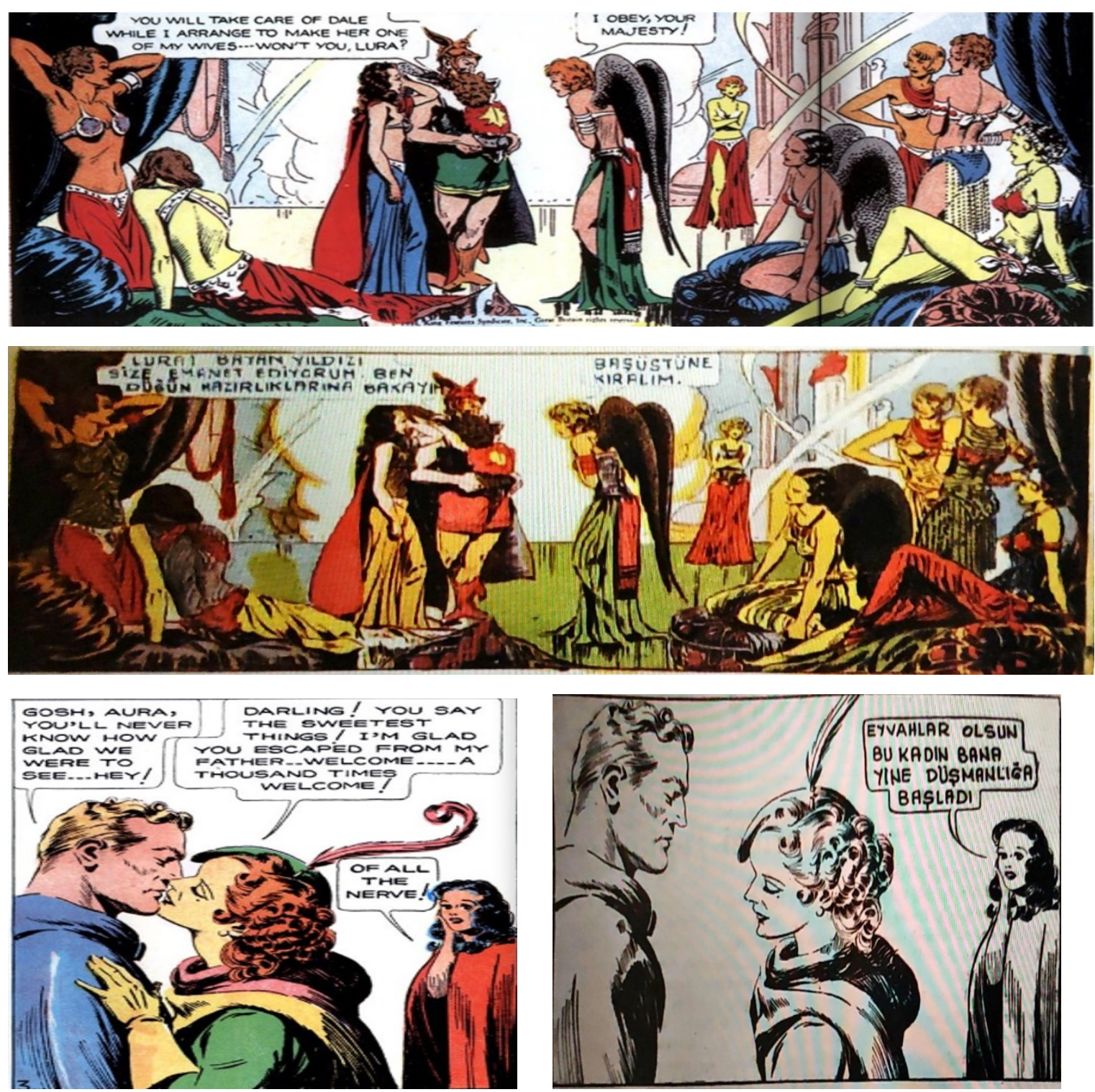

\section{Textual-linguistic norms in translating comics}

Gideon Toury (2012) maintains that translators face some social-cultural restrictions, which result in their choice of different strategies. In this section, textual-linguistic norms will be taken into consideration by a descriptive approach. Besides, "domestication" and "foreignisation" strategies offered by Venuti will be applied. Foreignisation strategy is preferred when the translator decides to take reader to the writer. Domestication is preferred when translator takes the writer to the reader (Venuti, 1993). As far as proper nouns are concerned in translation of Flash Gordon, it 
can be concluded that names of good main characters were domesticated whereas the bulk of others were subjected to phonetic spelling or not modified at all.

Table 1. Translation of proper names

\begin{tabular}{llll}
\hline Source Comic Strip & Target Comic Strip & Source Comic Strip & Target Comic Strip \\
\hline Flash Gordon & Baytekin & Barin & Barin \\
\hline Dale Arden & Bayan Yıldız & Ronkol & Sertgöz \\
\hline Dr. Hans Zarkov & Meşhur Alim Çetinel & Lura & Lura \\
\hline New York Times Square & İstanbul Taksim Meydanı & Azura & Azura \\
\hline Dr. Zarkov's Observatory & Kandilli Rasathanesi & Hhan & Han \\
\hline $\begin{array}{l}\text { Eastbound } \\
\text { Transcontinental }\end{array}$ & İstanbul Boğazı & Grumm & Girum \\
\hline Daily & Cumhuriyet Gazetesi & Chung & Şung \\
\hline Emperor Ming & Ming & Orax & Oraks \\
\hline Mongo & Mongo & Naquk & Nakuk \\
\hline Aura & Ora & Vultan & Vultan \\
\hline Kala & Kala & Mingo & Mingo \\
\hline Thun & Asi & Luong & Luong \\
\hline Undina & Undina & Commander Lu Chao & $---*$ \\
\hline Coralia & Mercan Şehir & Karakas & Karakaş \\
\hline Lord Pluton & Lord Pluton & Captain Truno & $---{ }^{*}$ \\
\hline Chiung & Illbay Pluton & & \\
\hline Triton & Cung & Arboria (bir yer adı) & $---*$ \\
\hline Chiung & Triton & Grombo & Grambo \\
\hline Luco & Ciyung & Dr. Bono & Dr. Bono \\
\hline Sonja & Luko & Chulan & Kulan \\
\hline Ruduk & Sonya & Kugor & Kugor \\
\hline Bulok & Ruduk & Lin- Chu & Minşo \\
\hline Ronal & Bulok & Arboria & Arboair \\
\hline Captain Solas & Ronal & Major Lingan & Albay \\
\hline & $---*$ & Chong & Song \\
\hline Lef & & &
\end{tabular}

*Left untranslated

\section{Conclusion}

The first translated comics in Turkish history following the alphabetic reform shows that comic strips were not taken as a multimodal medium. In target panels, as far as text and image relation is concerned, it can be concluded that they were more focused on text than pictures. The tangible proof of this strategy was deletion of 119 speech balloons and instead inserting additional text under panels. 363 of captions were deleted and replaced by additional texts. Although speech balloons and captions contain text, they were part of the pictorial in the end. It can be concluded that text and image relation was altered and text was more focused on in the target panels, which overshadowed the multimodality of comics. As the source comic strips were not produced for children, some adaptation strategies were applied to the target work possibly considering children as a key audience. Some didactic messages were conveyed to the reader and thus the periodical functioned as an instrument and part of the cultural planning repertoire. 82 censorship practices regarding pictorials were identified and most of which were applied to women's clothes. In terms of textuallinguistic norms, proper names are discussed. We found that domestication strategy was applied to 
the names of main characters in the early issues of the comic strip. However, most of other character names were used with phonetic spelling.

\section{References}

Borodo, M. (2015). Multimodality, Translation and Comics. Perspectives: Studies in Translatology, 22-41.

Borodo, M. (2016). Exploring the Links between Comics Translation and AVT. TranscUlturAl, 68-85.

Cantek, L. (2014). Türkiye'de Çizgi Roman . İstanbul: İletişim Yayınları.

Cantek, L. (2016). Türkiye'de Çizgili Romanın Umumi Manzarası. In L. Cantek, Çizgili Hayat Kılavuzu (pp. 15-27). İstanbul: İletişim.

Cohn, N. (2013). Beyond Speech Baloons and Thought Bubbles: The Integration of Text and Image. Semiotica, 35-63

Dicerto, S. (2018). Multimodal Pragmatics and Translation: A New Model for Source Text Analysis. Cham: Palgrave Macmillan.

Dollerup, C., \& Cay, M. (2003). 'Loss' and 'gain' in comics. Perspectives: Studies in Translatology, 197-216.

Duncan, R., \& Smith, M. J. (2009). The Power of Comics: History, Form, and Culture. New York: The Continuum International Publishing Group Inc.

Duncan, R., \& Smith, M. J. (2013). Icons of the American comic book: from Captain America to Wonder Woman. Greenwood.

Eisner, W. (1985). Comics\&Sequential Art. Florida: Poorhouse Press.

Even-Zohar, I. (1990). Polysystem Studies. Poetcis Today 11:1, 1-268.

Even-Zohar, I. (2012). The Podition of Translated Literature Within The Literary Polysystem. In L. Venuti, The Translation Studies Reader (pp. 162-168). New York: Routledge.

Groensteen, T. (2009). Why Are Comics Still in Search of? In J. Heer, \& K. Worcester, A Comics Studies Reader (pp. 311). University Press of Mississippi.

Groensteen, T. (2013). Comics and Narration. University Press of Mississippi.

Gürçağlar, Ş. T. (2008). Çoğuldizge Kuramı: Uygulamalar Eleştiriler. M. Rifat içinde, Çeviri Seçkisi (pp. 193-210). İstanbul: Sel Yayıncilik.

Gürçağlar, Ş. T. (2018). Türkiye'de Çevririnin Politikası ve Poetikası 1923-1960. İstanbul: Türkiye İş Bankası Kültür Yayınları

Harvey, R. (2009). How Comics Came to Be. J. Heer, \& K. Worcester içinde, A Comics Studies Reader (pp. 25-45). University Press of Mississippi.

Kaindl, K. (1999). Thump, Whizz, Poom: A Framework for the Study of Comics Under. Target, 263-288.

Kaindl, K. (2004). Multimodality in the translation of humour in comics. In E. Ventola, C. Charles, \& M. Kaltenbacher, Perspectives on Multimodality (pp. 172-192).

Kress, G., \& Leeuwen, T. V. (2006). Reading Images: The Grammar of Visual Design. New York: Routledge.

Lefevre, P., \& Dierick, C. (1998). Forging a New Medium: The Comic Strip in the Nineteenth Century. Brussels: Vubpress.

Martinec, R., \& Salway, A. (2005). A system for image-text relations in new (and old) media. Visual Communication, 337-371

McCloud, S. (1994). Understanding Comics: The Invisible Art. New York: HarperCollins.

Marsh, E. E., \& White, M. D. (2003). A taxonomy of relationships between images and text. Journal of Documentation, 647-672.

Pastra, K. (2008). COSMOROE: A Cross-Media Relations Framework for Modelling Multimedia Dialectics. Multimedia Systems, 299-323.

Rota, V. (2008). Aspects of adaptation: The Translation of Comics Formats. In F. Zanettin, Comics in Translation (pp. 79-98). Manchester: St. Jerome Publishing.

Sinibaldi, C. (2016). Between Censorship and Innovation: The Translation of American Comics during Italian Fascism. New Readings, 1-22.

Smolderen, T. (2014). The Origins of Comics: From William Hogarth to Winsor McCay. University Press of Mississippi.

Venuti, L. (1995). The Translator's Invisibility: A History of Translation. London: Routledge.

Venuti, L. (2012). Genealogies of Translation Theory: Jerome. In L. Venuti, The Translation Studies Reader (pp. 483503). New York: Routledge. 
142 Comics and Translation with a Multimodal Perspective in the Early Republican Era

Zanettin, F. (2008). Comics in Translation: An Overview. In F. Zanettin, Comics in Translation (p. 1). Manchester: St. Jerome Publishing.

Zanettin, F. (2008). The Translation of Comics as Localization: On Three Italian Translations of la piste des Navajos. In F. Zanettin, Comics in Translation (pp.152-171). (pp. 200-219). Manchester: St. Jerome Publishing. 